\title{
Effect of Retorting Temperature on the Pyrolysis Characteristic of Longkou Oil Shale
}

\author{
Wei Wang, ${ }^{1,2}$ Yue Ma, ${ }^{3}$ Shuyuan $\mathrm{Li}^{3}$ Changtao Yue, ${ }^{3}$ and Jiancun Gao $\mathbb{D}^{1,2}$ \\ ${ }^{1}$ School of Safety Engineering, Beijing Institute of Petrochemical Technology, Beijing 102617, China \\ ${ }^{2}$ Beijing Academy of Safety Engineering and Technology, Beijing 102617, China \\ ${ }^{3}$ State Key Laboratory of Heavy Oil Processing, China University of Petroleum, Beijing 102249, China
}

Correspondence should be addressed to Jiancun Gao; gaojiancun@bipt.edu.cn

Received 17 June 2021; Revised 25 August 2021; Accepted 9 September 2021; Published 7 October 2021

Academic Editor: Bo Liu

Copyright (c) 2021 Wei Wang et al. This is an open access article distributed under the Creative Commons Attribution License, which permits unrestricted use, distribution, and reproduction in any medium, provided the original work is properly cited.

Oil shale samples from Longkou City, Shandong Province, China, were pyrolyzed in a fixed bed reactor at retorting temperature varied from 400 to $550^{\circ} \mathrm{C}$ under nitrogen atmosphere with heating rate of $15^{\circ} \mathrm{C} / \mathrm{min}$. The influence of retorting temperature on the yield and characteristics of shale oil and retorting gases were determined. It was observed that the oil yield increased to the maximum value, $15.68 \mathrm{wt} \%$, as the retorting temperature increased from 440 to $550^{\circ} \mathrm{C}$. And increasing retorting temperature improved also gas yields, but reduced the char yield. The contents of $\mathrm{H}_{2}, \mathrm{CO}_{2}$, and $\mathrm{CH}_{4}$ in the retorting gas increased with the rising of retorting temperature. The ratio of alkane/alkene hydrocarbon $\left(\mathrm{C}_{1}-\mathrm{C}_{5}\right)$ decreased because of the secondary cracking reactions of gas phase in the high temperature. The carbon and nitrogen contents of shale oil increased with increasing retorting temperature, while those of hydrogen and oxygen decreased. The sulfur content was not significantly affected by the retorting temperature. In addition, the shale oil obtained from $550^{\circ} \mathrm{C}$ had the lowest aromatic content, $25.12 \mathrm{wt} \%$, and the highest saturate content, $50.03 \mathrm{wt} \%$, compared to the other retorting temperatures due to the cracking of aliphatic compounds. The alkanes with 8-34 carbons and alkenes with 8-27 carbons were detected in the shale oil. The concentration more than $20 \mathrm{mg} / \mathrm{g}_{\text {oil }}$ was $\mathrm{C}_{23}-\mathrm{C}_{30}$ in the range of $400-550^{\circ} \mathrm{C}$. The total content of n-alkanes decreased to $369.25 \mathrm{mgg}^{-1}$ oil , and that of $\mathrm{n}$-alkene reached the maximum value at $550^{\circ} \mathrm{C}, 181.62 \mathrm{mg} / \mathrm{g}_{\text {oil }}$, with the rise of retorting temperature. It was demonstrated that the higher temperature was beneficial to promoting the reaction of aromatization, dehydrogenation, fraction, and other reactions in the pyrolysis process.

\section{Introduction}

The effective development of oil shale resources could alleviate the global energy crisis, of which the global resources amount to $411 \times 10^{9} \mathrm{t}$ and the China's reserves of approximately $505 \times 10^{8} \mathrm{t}$ rank third among countries worldwide [1-4]. Containing 20-50\% organic matter and 50-80\% inorganic mineral, oil shale can be converted to shale oil, semicoke, water, and retorting gas by heating. Shale oil can be used as a component of marine fuels and light oils, such as gasoline and diesel oil. Hence, it is necessary to study the effect of pyrolysis factor on the pyrolysis characteristic of oil shale in order to increase the oil yield and upgrade its quality [5-7].
So far, there have been various studies for the efficient recovery of shale oil from oil shale [8-11]. Wang et al. [8, 9] investigated the influence of heating rate and retorting temperature on pyrolysis characteristics of Dachengzi oil shale pyrolysates. It was noticed that increasing temperature was beneficial to the yield and quality of shale oil, causing a drop of oil/gas yield ratio because of the secondary cracking reactions. Wang et al. [10] optimized the pyrolysis condition of Longkou oil shale, such as nitrogen flow rate, retorting temperature, particle size, and heating rate in order to reduce the secondary reactions. Oil yield reached the maximum value, $17.46 \%$, higher than Fischer assay oil yield, at heating rate $15^{\circ} \mathrm{C} / \mathrm{min}$ up to $550^{\circ} \mathrm{C}$ under $0.6 \mathrm{~L} / \mathrm{min}$ nitrogen flow rate for 2 to $3 \mathrm{~mm}$ oil shale particles. TGA-MS was used 
to analyze the pyrolysis characteristics of Green River oil shale [11]. It was noted that the compositions of products were affected by the fundamental chemistry of the organic matter decomposition in oil shale and overall system or reactor configuration. Amounts of alkenes were produced during the pyrolysis process, in which the increase of alkenes to alkanes ratio as the heating rate rose. Dung [12] found out that the retorting temperature was the only factor to influence the $\mathrm{H} / \mathrm{C}$ atomic and nitrogen content of shale oil derived from Stuart and Condor oil shale. Jaber and Probert [13] indicated that the main region of pyrolysis was in the range of $200-600^{\circ} \mathrm{C}$. And the oil yield and the extent of any oil cracking were greatly influenced by the final retorting temperature. Al-Ayed et al. [14] pointed out that the oil yield decreased from $80 \%$ to $40 \%$ when heating rate was increasing from 0.2 to $13^{\circ} \mathrm{C} / \mathrm{min}$ in fixed-bed retort, which was linked to the secondary cracking reactions. What is more, the oil yield and retorting gas were affected by the particle size. It was showed that shale oil yield firstly increased and then descended when the particle size increased from 10 to $40 \mathrm{~mm}$ [15]. It was attributed to the diffusion influence of large particle size. Besides, many studies focused on the thermogravimetric analyses for pyrolysis kinetics of oil shale. $\mathrm{Li}$ and Yue [16] studied the pyrolysis kinetics of different Chinese oil shale samples at a heating rate of $5 \mathrm{~K} / \mathrm{min}$ using a special kinetic model involving 11 parallel first-order reactions. The parallel reactions with different apparent activation energy and frequency factors occurred simultaneously. It was found that the apparent activation energies were in the range of $120-240 \mathrm{~kJ} / \mathrm{mol}$. Abu-Qudais et al. [17] investigated the kinetics of pyrolysis of Attarat oil shale in Jordan using a thermogravimetric analyzer. Two kinetic expressions for each heating rate were proposed, standing for two steps of decomposition. Doğan and Uysal [18] and Torrente and Galan [19] investigated the pyrolysis kinetics of Turkish and Spanish oil shale using first-order kinetics models including integral method, differential method, Friedman procedure, and maximum rate method. Mustafa Versan Kok and Senguler studied oil shale samples nonisothermally using thermogravimetry analysis [20]. In the combustion process, kinetic parameters of the samples were determined by Kissinger and KAS kinetic models. The results showed that the activation energy values were almost the same with each other in three different kinetic models studied. The differences were mainly contributed to the different equation parameters or the assumptions that those models are based on. However, few researches have investigated the effect of retorting temperature on the contents of alkanes and alkenes in the shale oil. Because the quality of shale oil recovered is eager to upgrade to improve its economic value [21], additional upgrading processes are required.

Therefore, not only yield but also properties of retorting gas should be considered. In this study, the effects of retorting temperature on the pyrolysates of Longkou oil shale were investigated in the range of $400-550^{\circ} \mathrm{C}$. And the comparisons of characteristics of pyrolysates under different retorting temperatures, including the compositions of retorting gas, high-temperature simulated distillation, SARA fractions, and ultimate analysis of shale oil, were performed. The semi- quantitative analysis of alkanes and alkenes in shale oil by GC-MS was also investigated. In other words, a uniform experimental design was rare to discuss effects of retorting temperature on different pyrolysis responses.

\section{Experimental}

2.1. Samples and Pretreatment. The oil shale used in this work was from Longkou City, located in Shandong Province of China. During the experiments, the samples were crushed to $0-6 \mathrm{~mm}$ particles according to the National Standards: GB/T 19494.2-2004 Mechanical sampling of coal-Part 2: Method for sample preparation. Fischer assay was carried out according to ASTM standards (ASTM D3904-90). The proximate analysis and ultimate analysis were conducted using a HTGF-3000 analyzer (Hebi Huatai Instrument Measuring Appliance Co. Ltd.) and a LECO CHN-2000(LECO, USA) and LECO S-144DR analyzer (LECO, USA), respectively. Samples were stored in sealed containers at room temperature, and there was no measurable change in its moisture content over the course of experiments. The basic properties of Longkou oil shale are presented in Table 1.

2.2. Pyrolysis Equipment. Figure 1 shows the schematic diagram of the fixed bed apparatus in laboratory scale. The fixed-bed reactor placed with $50 \mathrm{~g}$ sample was electrically heated at $15^{\circ} \mathrm{C} / \mathrm{min}$ heating rates under $0.6 \mathrm{~L} / \mathrm{min} \mathrm{N}_{2}$ atmosphere to different final temperatures with the range of 400 $550^{\circ} \mathrm{C}$. In order to minimize secondary reaction, nitrogen was introduced from the bottom of pyrolysis reactor to evenly sweep the generated products toward the side outlet of reactor. The liquid condenser was consisted of a glass liner contained within a series of cold traps, maintained at $-22^{\circ} \mathrm{C}$ and connected to the reactor outlet. Serpentine condenser pipe was used to ensure that all the pyrolysis products had enough time to cool and collect the pyrolysis products uncooled in the condenser bottle although it was few. The reactor was cooled to the room temperature after the experiment ceased. The weight of semicoke was collected and weighted. The weight of the mixture of shale oil and water was the difference between the gross weight of bottles with condensate and empty bottles. The water content was determined by solvent extraction. The weight of shale oil was the difference between mixture and water. The noncondensable outlet gas was collected using gas bag from condenser pipe and analyzed by Agilent-6890 gas chromatograph.

In order to assess the reproducibility, each pyrolysis experiment was performed twice under identical conditions.

2.3. SARA Fractions. The collected shale oil was separated into four fractions (saturates $(S)$, aromatics $(A)$, resins $(R)$, and asphaltenes $(\mathrm{A})$ ) by a column chromatography on activated alumina using the National Standards: GB/SH/T 0509-2010. At first, shale oil was mixed with $50 \mathrm{~mL}$ of heptane for $12 \mathrm{~h}$. As the fraction of bitumen insoluble in heptane, the asphaltenes was collected after the mixture was filtered through a funnel covered with cotton wool. The separated soluble fractions were directed to column chromatography to obtain the saturates, aromatics, and 
TABle 1: Properties of Longkou oil shale (air received basis/ar\%).

\begin{tabular}{lcccccccccccc}
\hline \multicolumn{2}{l}{$\begin{array}{l}\text { Fisher assay/mass\% } \\
\text { Oil }\end{array}$} & Water & Semicoke & Gas & C & H & O & N & S & \multicolumn{4}{c}{ Proximate analysis/mass\% } & V & A & FC \\
\hline 14.14 & 5.34 & 74.87 & 5.65 & 32.05 & 2.91 & 12.09 & 0.19 & 1.42 & 2.25 & 39.72 & 51.09 & 6.94 \\
\hline
\end{tabular}

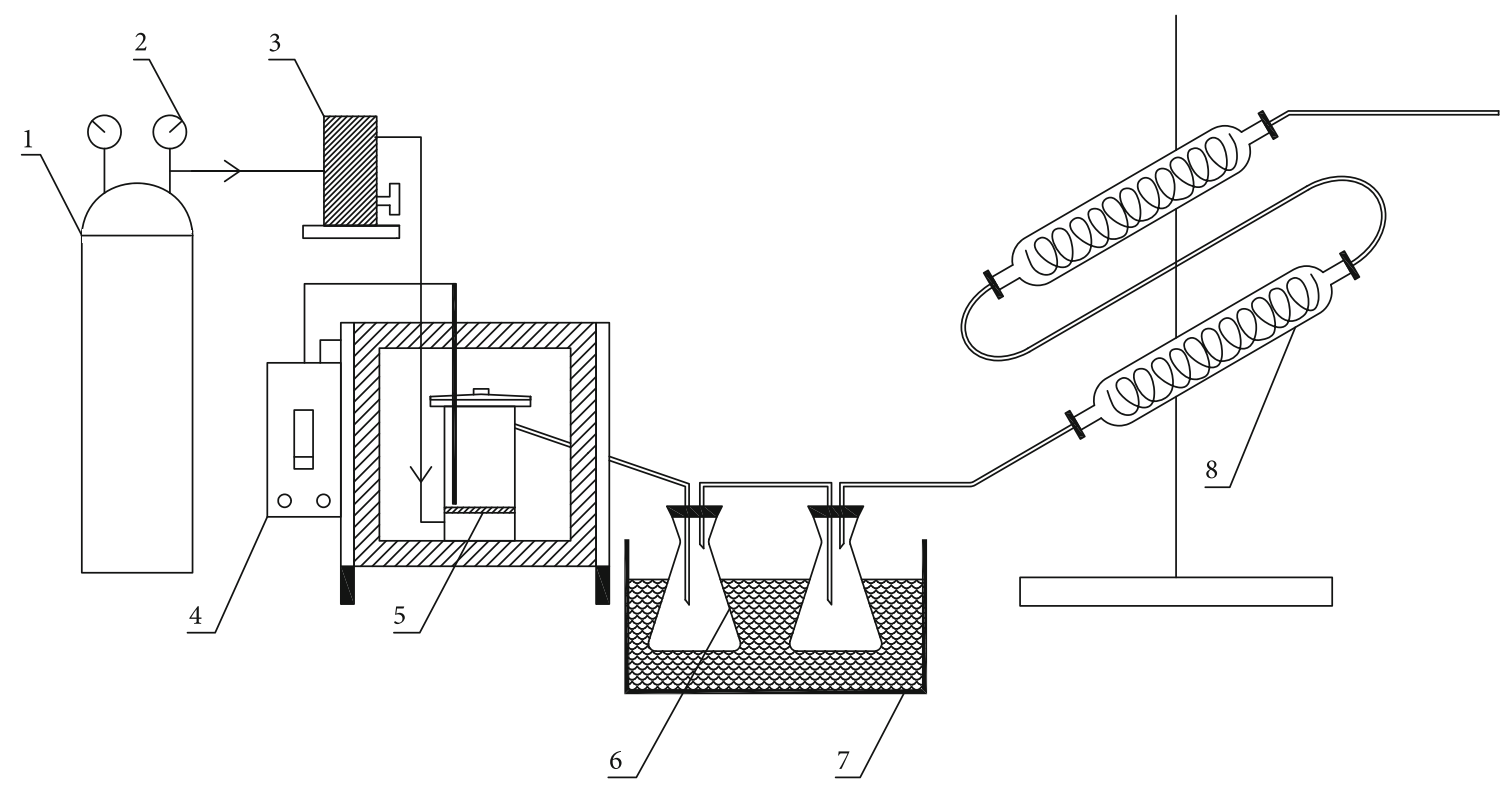

FIGURE 1: Simple schematic diagram of the fixed bed pyrolysis reactor. 1: carrier gas- $\mathrm{N}_{2} ; 2$ : valve; 3: flowmeter; 4 : heating furnace; 5 reactor; 6: collected bottle; 7: cold trap; 8: serpentine condenser pipe.

resins, respectively. It was eluted sequentially by heptane, methylbenzene, and methylbenzene-ethanol to obtain. A glass column ( $12 \mathrm{~mm}$ inner diameter $\times 950 \mathrm{~mm}$ length $)$ was packed with $40 \mathrm{~g}$ of aluminum oxide (80-100 mesh, activated at $500^{\circ} \mathrm{C}$ for $\left.6 \mathrm{~h}\right)$. Cotton wool was inserted at the bottom of the column. After the hexane-soluble matter was poured through the packed column, $80 \mathrm{~mL}$ of heptane was added to elute the saturate fraction. The aromatic fraction was obtained by eluting the column with $80 \mathrm{~mL}$ methylbenzene. And then, the mixture of methylbenzene-ethanol $(1: 1, v / v)$ was added to obtain the resin fraction.

2.4. High-Temperature Simulated Distillation. High-temperature simulated distillation was analyzed using the ASTM method HT 750 (AC Analytical Controls Method; Analytical Controls, Inc., USA) and performed an Agilent $6890 \mathrm{~N}$ gas chromatograph (Agilent Technologies, Inc., USA), which was equipped with an automatic injector. The carrier gas was helium (99.999\% purity) with a constant flow rate of $5 \mathrm{~mL} \mathrm{~min}^{-1}$. The GC contained a $15 \mathrm{~m} \times 0.53 \mathrm{~mm} \times 0.25 \mu \mathrm{m}$ capillary column (DB-1, Agilent Technologies, Inc., USA) with a cool on-column injector. Temperature programming for the column was $10^{\circ} \mathrm{C} / \mathrm{min}$ from $50^{\circ} \mathrm{C}$ to $450^{\circ} \mathrm{C}$ (maintain for $5 \mathrm{~min}$ ). The injector and flame ionization detector (FID) were held at 300 and $350^{\circ} \mathrm{C}$, respectively. About $10 \mathrm{mg}$ of shale oil sample was completely dissolved in $1 \mathrm{~mL}$ of carbon disulfide to analyze.
2.5. GC-MS Analysis. GC-MS analysis of shale oil was performed using Thermo Trace DSQ GC-MS equipped with a HP-5 MS column $(30 \mathrm{~m} \times 0.25 \mathrm{~mm} \times 0.25 \mu \mathrm{m})$. The GC oven was held at $50^{\circ} \mathrm{C}$ for $3 \mathrm{~min}$, increased to $300^{\circ} \mathrm{C}$ with heating rate of $5^{\circ} \mathrm{C} / \mathrm{min}$, and then held isothermal for $10 \mathrm{~min}$. The injector and transfer line temperatures were held at 300 and $250^{\circ} \mathrm{C}$, respectively. Helium was used as the carrier gas with $1 \mathrm{~mL} \mathrm{~min}^{-1}$ flow rate. Ion source temperature was maintained at $250^{\circ} \mathrm{C}$, and ionizing voltage was $70 \mathrm{eV}$.

About $10 \mathrm{mg}$ of shale oil sample was completely dissolved in $1 \mathrm{~mL}$ of dichloromethane. And $10 \mathrm{mg} \mathrm{mL}^{-1}$ standard $\mathrm{N}$-tetracosane-D50 diluted with $1 \mathrm{~mL} \mathrm{~N}$-hexane was added to the shale oil to semiquantitatively analyze the compositions of alkanes and alkenes.

2.6. GC Analysis. GC analysis of retorting gas was performed an Agilent 6890N gas chromatograph (Agilent Technologies, Inc., USA). The gas analyzer was consisted of a Hayesep-Q $5 \mathrm{~A}$ column $(5 \mathrm{~m} \times 0.32 \mathrm{~mm} \times 0.02 \mu \mathrm{m})$ with thermal conductivity detector (TCD) detector and a HP-PLOT S column $(50 \mathrm{~m} \times 0.53 \mathrm{~mm} \times 15 \mu \mathrm{m})$ with FID detector. The GC oven was held at $50^{\circ} \mathrm{C}$ for $10 \mathrm{~min}$, increased to $190^{\circ} \mathrm{C}$ with heating rate of $15^{\circ} \mathrm{C} / \mathrm{min}$, and then held isothermal for $15 \mathrm{~min}$. The injector and detector temperatures were held at 150 and $250^{\circ} \mathrm{C}$, respectively. Helium was used as the carrier gas with $38 \mathrm{~mL} / \mathrm{min}$ flow rate. The GC was recorded for the following 


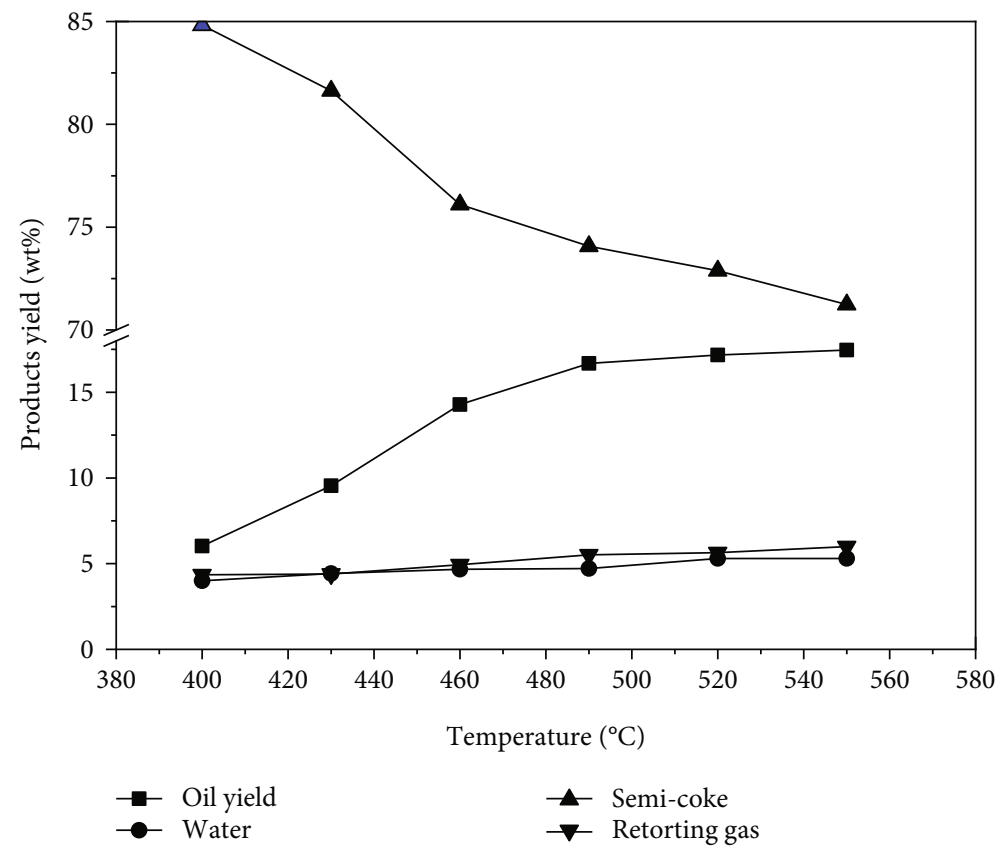

FIGURE 2: Effect of retorting temperature on yields of pyrolysates.

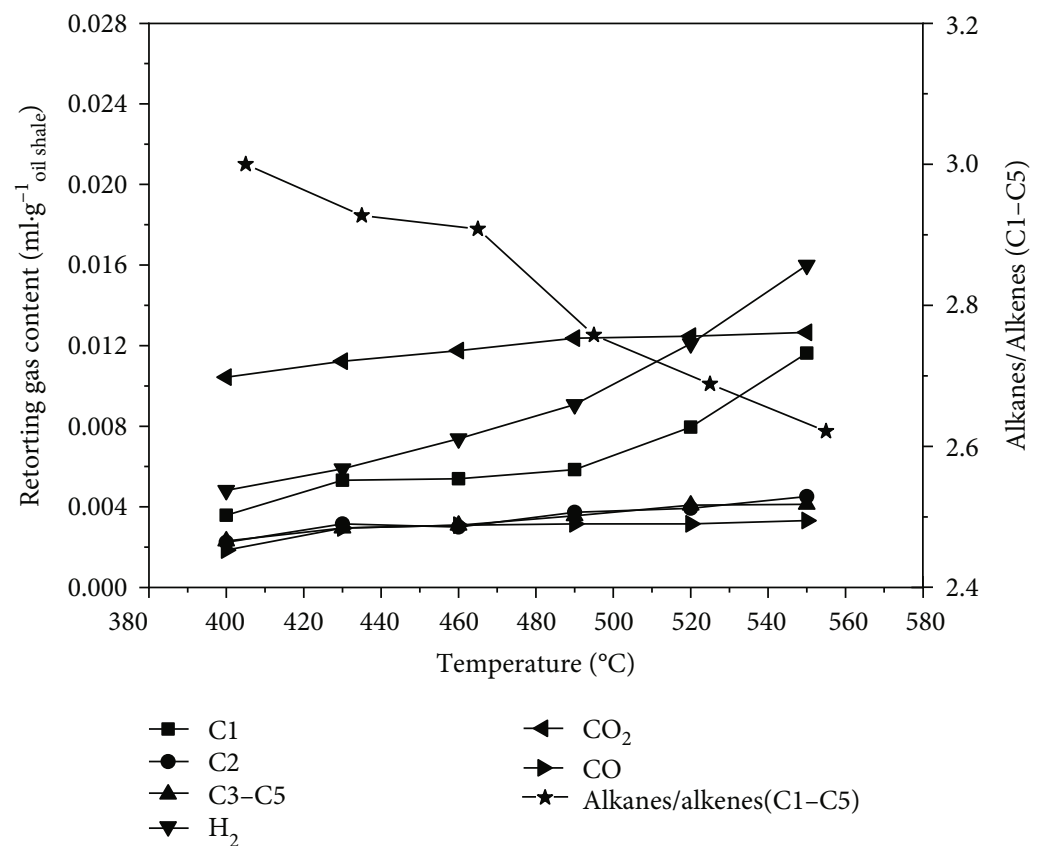

FIGURE 3: Effect of retorting temperature on composition of retorting gas.

components: $\mathrm{CH}_{4}, \mathrm{C}_{2} \mathrm{H}_{6}, \mathrm{C}_{2} \mathrm{H}_{4}, \mathrm{C}_{3} \mathrm{H}_{8}, \mathrm{C}_{3} \mathrm{H}_{6}, \mathrm{C}_{4} \mathrm{H}_{10}, \mathrm{C}_{4} \mathrm{H}_{8}$, $\mathrm{C}_{5} \mathrm{H}_{12}, \mathrm{C}_{5} \mathrm{H}_{10}, \mathrm{CO}, \mathrm{CO}_{2}$, and $\mathrm{H}_{2}$.

\section{Results and Discussion}

3.1. Products Yield. The oil yield of Longkou oil shale affected by final retorting temperature is showed in Figure 2. It was obvious that the semicoke content decreased from $81.83 \%$ to $71.04 \%$ as the final retorting temperature increased from $400^{\circ} \mathrm{C}$ to $550^{\circ} \mathrm{C}$. It means that the shale oil and retorting gas of oil shale can be increased by about $10 \%$ by increasing the retorting temperature. Hence, the retorting temperature was the main factor affecting the pyrolysis process of oil shale. When the retorting temperature increased from $400^{\circ} \mathrm{C}$ to $520^{\circ} \mathrm{C}$, the oil yield increased from $6.02 \%$ to $15.68 \mathrm{wt} \%$ due to the split of strong chemical bonds in aromatic rings and heterocyclic and alicyclic compounds. So, the main pyrolysis reaction zone of oil shale was 


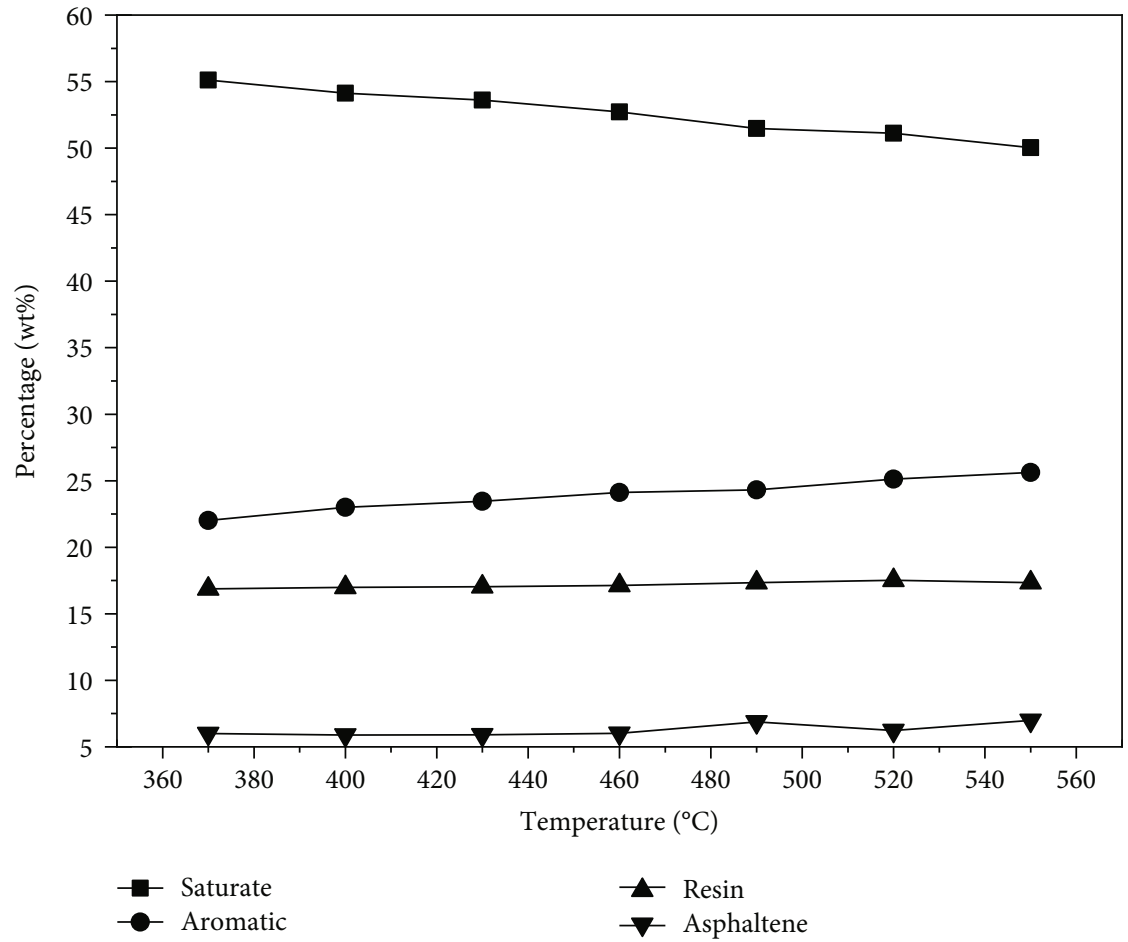

FIGURE 4: Effect of retorting temperature on SARA fractions of shale oil.

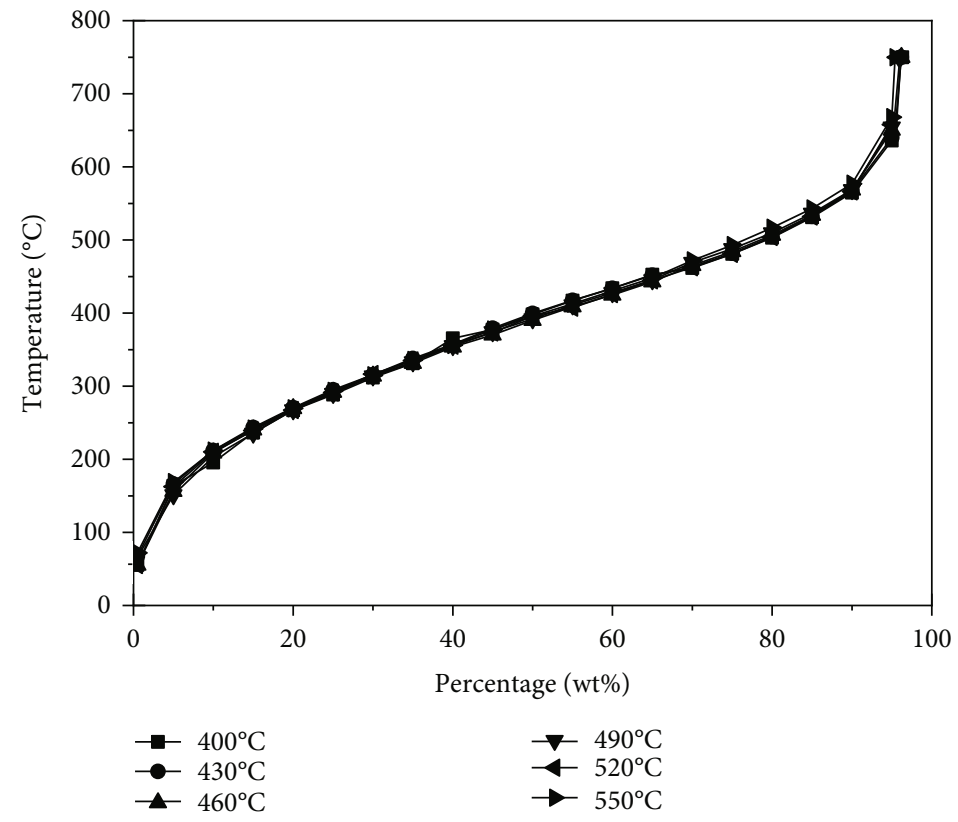

FIGURE 5: Effect of retorting temperature on the simulated distillation curves of shale oil.

in the range of $400-520^{\circ} \mathrm{C}$. After then, the oil yield continued to increase slowly from $520^{\circ} \mathrm{C}$ to $550^{\circ} \mathrm{C}$ as the incomplete pyrolysis at low retorting temperature occurred. It was indicated the end of conversion of high molecular organic compounds to oil [22-24]. Above it, the shale oil yield may reduce due to the polycondensation and aromatization reactions of oil $[23,24]$. During the whole temperature-rising stage, the content of water and retort gas increased slowly as they were released with the formation of shale oil during pyrolysis process. So, $550^{\circ} \mathrm{C}$ was selected as the optimal temperature.

3.2. Compositions of Retorting Gas. Figure 3 shows the influence of final retorting temperature of oil shale on the composition of retorting gas. Obviously, the retorting gases were mainly $\mathrm{CH}_{4}, \mathrm{CO}_{2}$, and $\mathrm{H}_{2}$ in the initial pyrolysis 


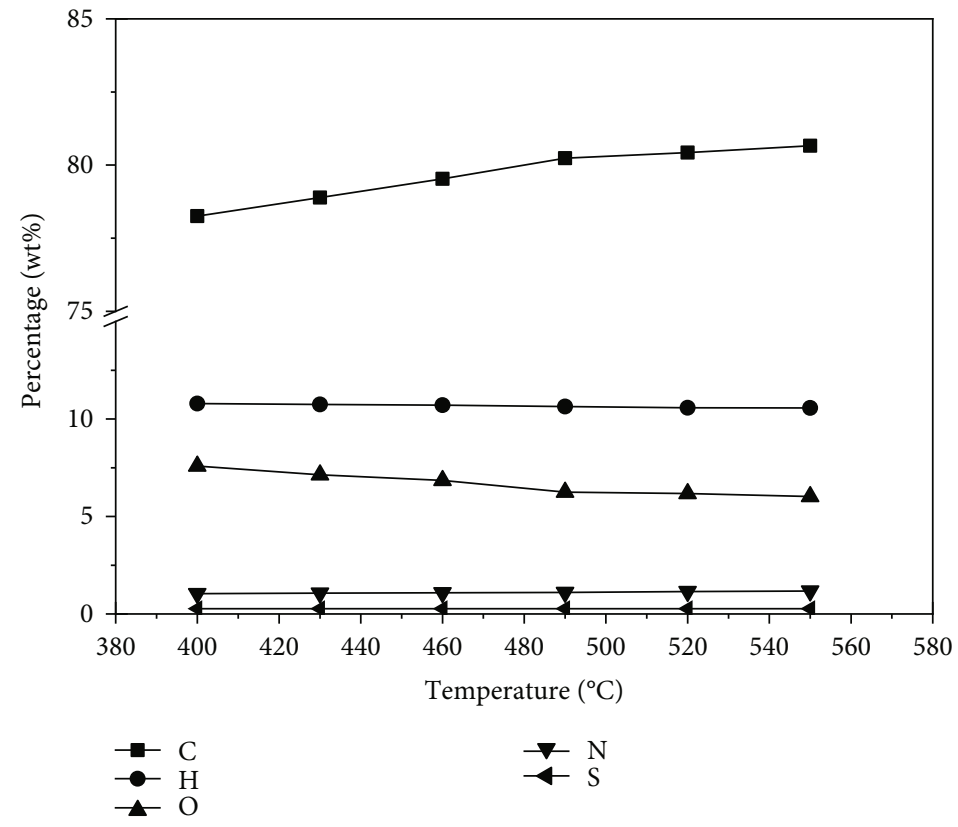

FIGURE 6: Effect of retorting temperature on CHONS content in shale oil.

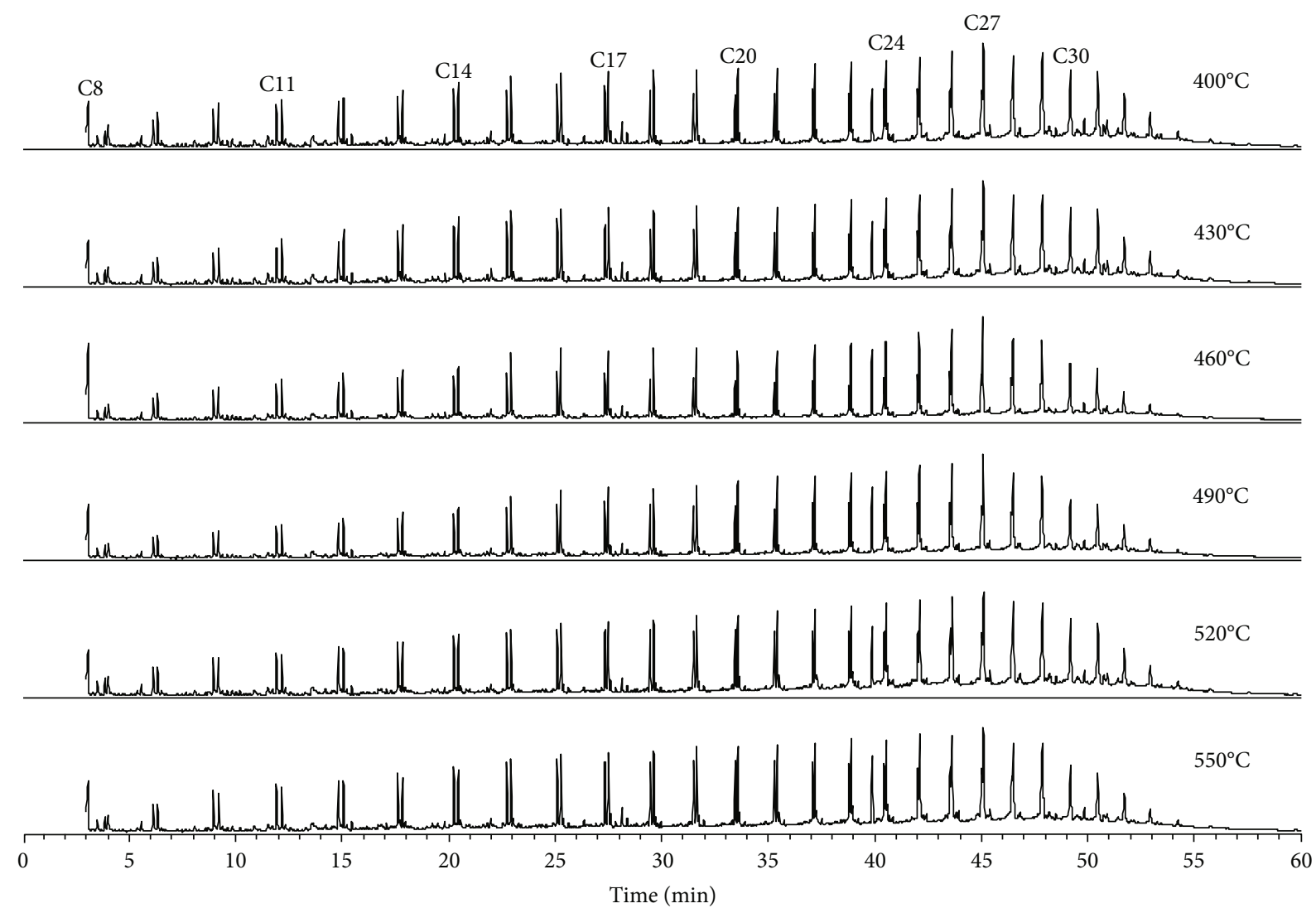

Figure 7: TIC of shale oil at different retorting temperatures.

process. As the temperature rose, the organic matter in the oil shale began to decompose, and many small molecular gases and volatile products were generated. So, the retorting gas products mainly included inorganic gases and small molecular hydrocarbons of $\mathrm{C}_{1}-\mathrm{C}_{5}$. The light compounds $\left(\mathrm{C}_{1}-\mathrm{C}_{5}\right)$ were mainly generated from the cracking of 
macromolecule or some side chains, containing methane, ethane, propane, butane, pentane, ethene, propene, butene, and pentene. In the range of $350-400^{\circ} \mathrm{C}$, the increase of $\mathrm{CO}_{2}$ and $\mathrm{CO}$ content was ascribed to the decarboxylation reaction of the oxygen-containing functional groups. But in the higher temperature range, the rise of their contents possibly caused by the break of the carbonyl group [25].

Besides, the ratio of alkanes $\left(\mathrm{C}_{1}-\mathrm{C}_{5}\right)$ /alkenes $\left(\mathrm{C}_{2}-\mathrm{C}_{4}\right)$ decreases with the rise of the final temperature. The change of ratio is linked to the secondary cracking reaction. The higher the retorting temperature, the more the gas cracking and secondary gas phase reactions $[26,27]$.

When the retorting temperature reached $490^{\circ} \mathrm{C}$, the content of $\mathrm{H}_{2}$ increased rapidly. The generation of $\mathrm{H}_{2}$ mainly came from two reactions: one was the condensation polymerization reaction between free radicals and the other was the condensation and aromatization reaction of pyrolysis products. At higher temperatures, alkanes were prone to decomposition and dehydrogenation due to lower bond energy, leading to higher olefin and $\mathrm{H}_{2}$ content. With the increase of temperature, the ratio of alkanes to alkenes in the retorting gas decreased, indicating that high temperature intensifies the secondary cracking reaction of gas.

3.3. SARA Fractions. Figure 4 provides the results of SARA fractions of shale oil obtained from different retorting temperatures. It was obvious that the aromatics, resins, and asphaltenes in shale oil increase as the retorting temperature rose from 400 to $550^{\circ} \mathrm{C}$. The increase of aromatic fraction may be caused by the increase of aromatization at high temperature. It has been reported that aromatic compounds were generated from the cracking of aliphatic compounds or Diels-Alder type reactions $[28,29]$. The cracking reaction was dominant in the high temperature, and the long-chain aliphatic hydrocarbons were fractured to generate more aromatic components, decreasing the content of saturates' fraction from $54.12 \mathrm{wt} \%$ to $50.03 \mathrm{wt} \%$. In addition, the strong thermodynamic stability of aromatic fraction was also another reason for the increase of aromatic fraction.

The increase of asphaltene fraction could be interpreted by the pyrolysis mechanism of bitumen as the intermediate product [30]. The bitumen was converted into asphaltenes and other products during the pyrolysis process.

3.4. High-Temperature Simulated Distillation. Figure 5 shows the simulation distillation curves of shale oil obtained at different pyrolysis final temperatures $\left(400-550^{\circ} \mathrm{C}\right)$. It can be seen from the figure that there was little difference in the distillate distribution of shale oil at different final temperatures. The curve of simulation distillation moved upward slightly as the final temperature of pyrolysis increased, indicating that the final temperature of pyrolysis has hardly affected on the distillation range distribution of shale oil.

3.5. Ultimate Analysis of Shale Oil. The ultimate results of shale oil are depicted in Figure 6. Obviously, the C content in shale oil increased by about $3 \mathrm{wt} \%$, and the $\mathrm{H}$ content decreased slightly when the final retorting temperature rose
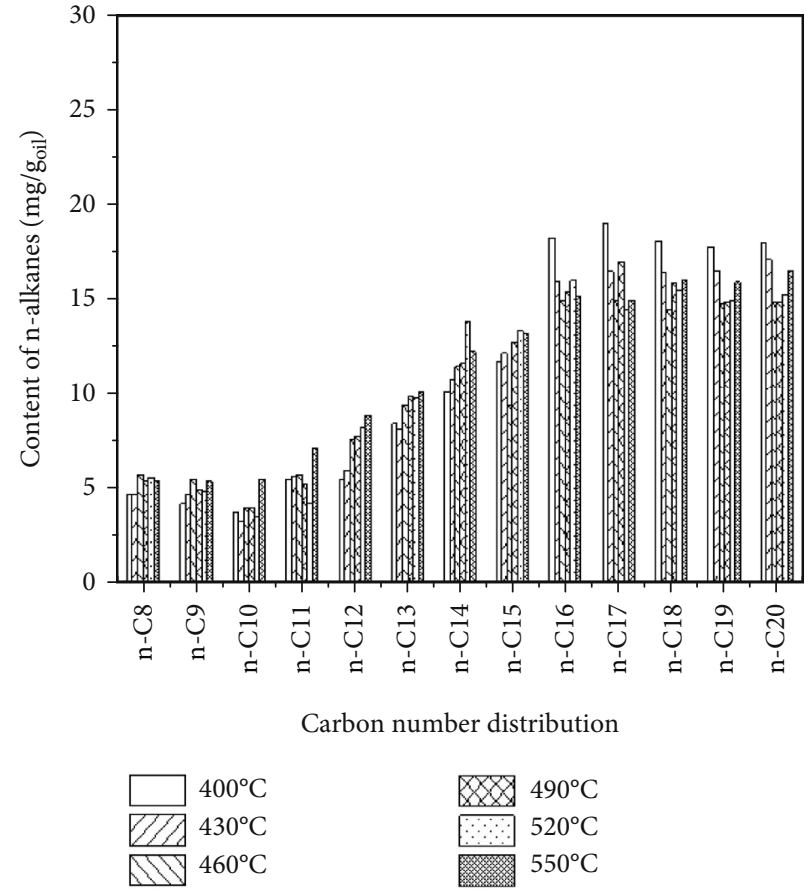

FIgURE 8: Effect of retorting temperature on content of C8-C20 n-alkanes in shale oil.

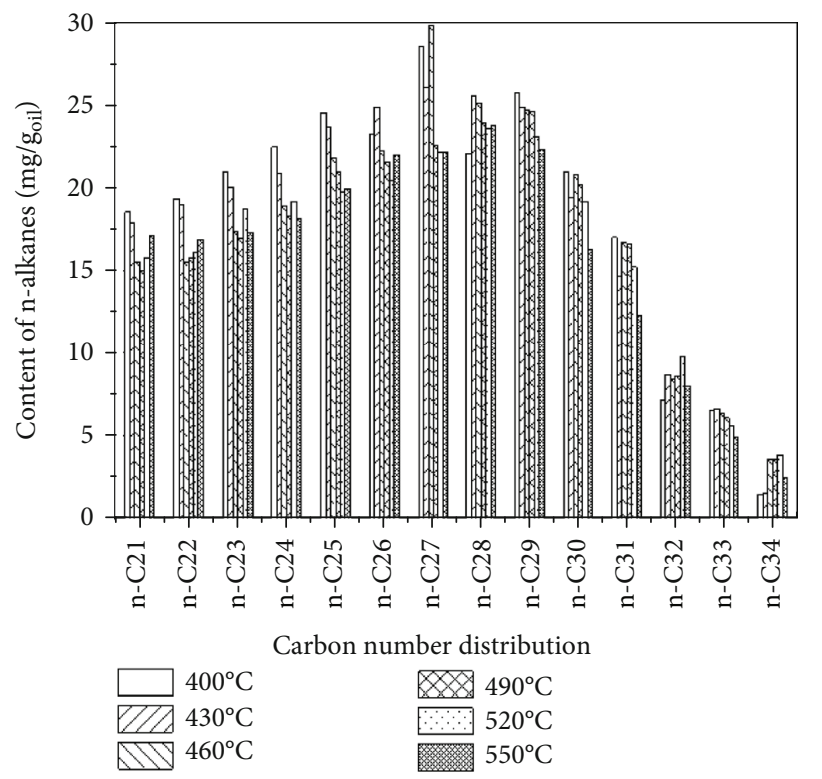

FIGURE 9: Effect of retorting temperature on content of C21-C34 n-alkanes in shale oil.

from 400 to $550^{\circ} \mathrm{C}$. It means that the $\mathrm{H} / \mathrm{C}$ ratio decreased with the increase of the final retorting temperature, which may be caused by aromatization, dehydrogenation, and coking reactions. The result was the same with that of SARA.

The $\mathrm{O}$ content decreased from $7.59 \mathrm{wt} \%$ at $400^{\circ} \mathrm{C}$ to $6.02 \mathrm{wt} \%$ at $550^{\circ} \mathrm{C}$ due to the oxygen-containing functional groups decompose rapidly due to thermodynamic instability in the high temperature. The higher the temperature, the easier it was to generate small molecular oxides, resulting 


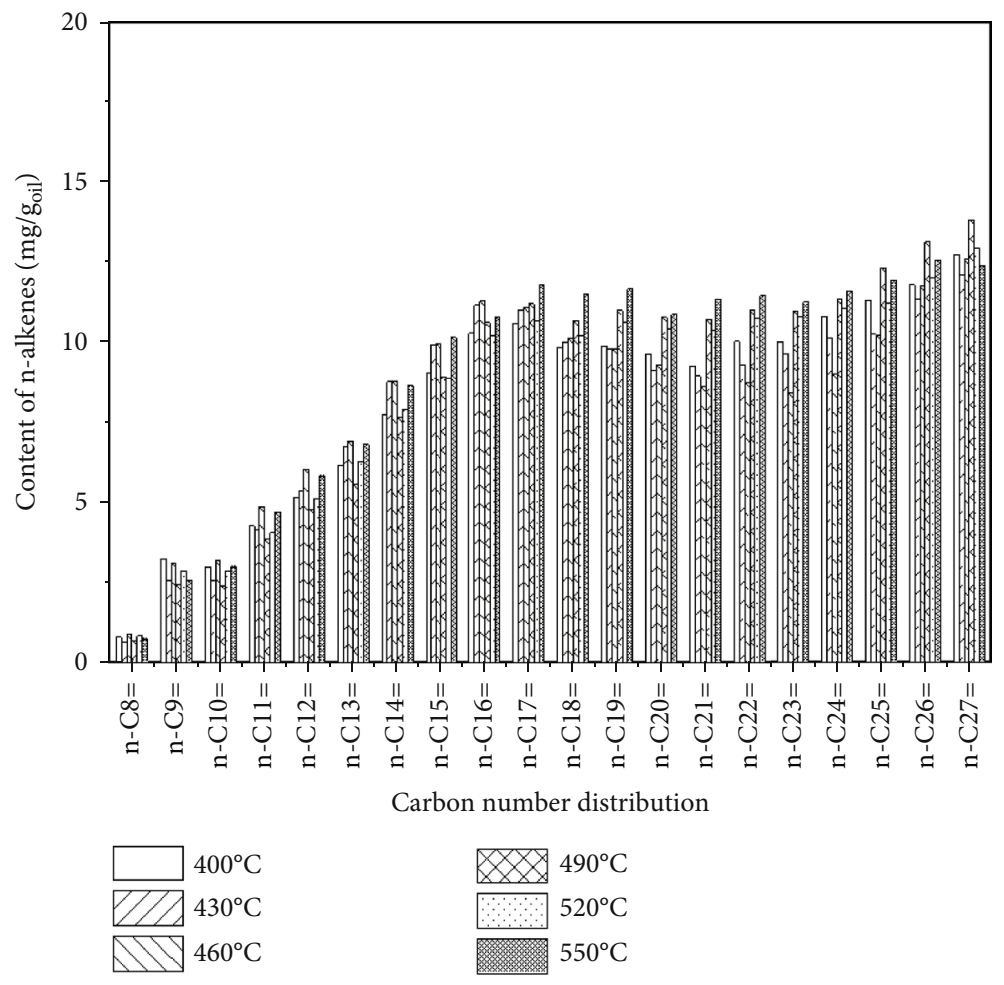

Figure 10: Effect of retorting temperature on content of C8-C27 n-alkenes in shale oil.

in the decrease of oxygen content in shale oil. The $\mathrm{N}$ content increased slightly with the increase of temperature, which was attributed to the aromatization reaction to form polycyclic aromatic nitrogenous compounds in the high temperature. However, the increase of temperature had little effect on the content of $S$ element. S compounds can stably exist in shale oil due to their strong thermodynamic stability.

3.6. GC-MS Analysis for Shale Oil. Figure 7 describes the effect of the final retorting temperature on the total ion chromatogram of shale oil. It was observed that the ion distribution of shale oil obtained from different retorting temperatures was similar, indicating the molecular components of shale oil were unchanged by changing the retorting temperature. $\mathrm{N}$-alkanes with 8-34 carbons and n-alkenes with 8-27 carbons were detected. Most of compounds were concentrated on the heavier compounds of shale oil. In addition, the difference of peak area and height of standard $\mathrm{N}$-tetracosane- $\mathrm{D}_{50}$ is less than $5 \%$ to eliminate the systematic errors. The relative intensity of the MS spectrum was estimated according to the area ratio of a peak to the peak of $n-C_{24} D_{50}$. And the concentration $\left(\mathrm{mg} / \mathrm{g}_{\text {oil }}\right)$ of alkene and alkane compounds is depicted in Figures 8 and 9, respectively. The concentration more than $20 \mathrm{mg} / \mathrm{g}_{\text {oil }}$ was $\mathrm{C}_{23}-\mathrm{C}_{30}$ in the range of $400-550^{\circ} \mathrm{C}$. The maximum concentration in the range of $400-550^{\circ} \mathrm{C}$ was $\mathrm{C}_{27}$ to $\mathrm{C}_{29}$, especially the concentration of $\mathrm{C}_{27}$ at $460^{\circ} \mathrm{C}$ reached to the maximum value with $30 \mathrm{mg} / \mathrm{g}_{\text {oil }}$ because of the rapidly cracking of macromolecular components in oil shale [9]. What is more, the main contents of shale oil were $\mathrm{C}_{16^{-}} \mathrm{C}_{30}$ in the range of $400-460^{\circ} \mathrm{C}$, but $\mathrm{C}_{22^{-}}$ $\mathrm{C}_{29}$ ranging from $460^{\circ} \mathrm{C}$ to $550^{\circ} \mathrm{C}$. And when the retorting tem- perature increased from $400^{\circ} \mathrm{C}$ to $550^{\circ} \mathrm{C}$, the content of nalkanes with $\mathrm{C}_{8}-\mathrm{C}_{15}$ in shale oil gradually increased, especially the content of $\mathrm{C}_{8}-\mathrm{C}_{12}$ n-alkanes with an increase of about 2$4 \mathrm{mg} / \mathrm{g}_{\text {oil }}$. But the content of $\mathrm{C}_{16}-\mathrm{C}_{34} \mathrm{n}$-alkanes decreased as the secondary fracture reaction of long-chain alkanes occurred in the higher temperature. Although the secondary cracking of long-chain alkanes in shale oil was demonstrated to take place, the generating rate of shale oil was faster than the cracking rate as the oil yield reached to the maximum value.

Figure 10 shows the effect of the retorting temperature on the content of $\mathrm{C}_{8}-\mathrm{C}_{27} \mathrm{n}$-alkenes in shale oil. The content of $\mathrm{C}_{8}-\mathrm{C}_{20} \mathrm{n}$-alkenes increased with the rise of retorting temperature, while that of $\mathrm{C}_{21}-\mathrm{C}_{27} \mathrm{n}$-alkenes decreased. The larger the carbon number of an alkane, the smaller the bond energy between its $\mathrm{C}-\mathrm{C}$ bond and $\mathrm{C}-\mathrm{H}$ bond, and the worse its stability. Therefore, long-chain $\mathrm{n}$-alkanes were easy to crack or dehydrogenize at high temperatures to generate short-chain alkanes and alkenes. Therefore, the higher the temperature, the higher the content of $\mathrm{C}_{8}-\mathrm{C}_{15}$ alkanes and $\mathrm{C}_{8}-\mathrm{C}_{20}$ alkenes, and the lower the content of long-chain alkanes. Besides, long-chain alkenes may undergo fracture, dehydrogenation, and aromatization reactions at high temperature, resulting in a decrease in its content and an increase in the content of short-chain alkenes [10].

Figure 11 shows the variation of $n$-alkane and $n$-alkene contents at different retorting temperatures. With the increase of the retorting temperature, the content of $n$ alkanes decreased from 402.91 to $369.25 \mathrm{mg} / \mathrm{g}_{\text {oil }}$, a decrease of about $43 \mathrm{mg} / \mathrm{g}_{\text {oil }}$. The total amount of $\mathrm{n}$-alkene reached the maximum value at $550^{\circ} \mathrm{C}, 181.62 \mathrm{mg} / \mathrm{g}_{\text {oil }}$. The change trend of $n$-alkane and $n$-alkene contents was opposite with 


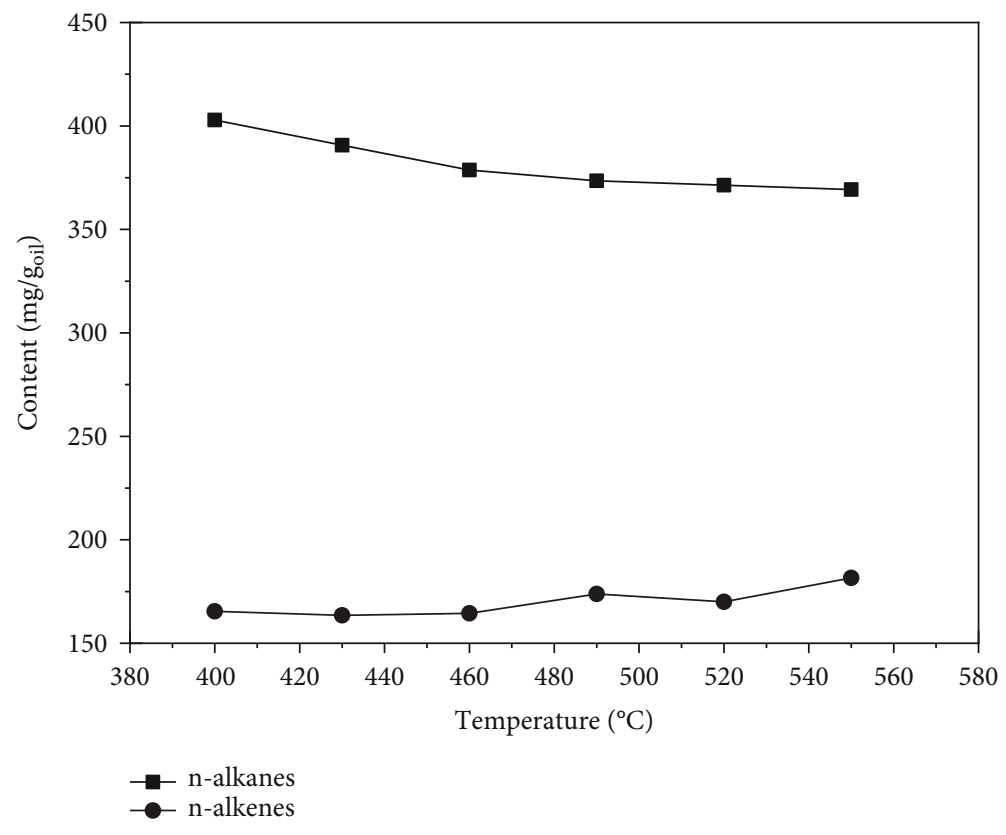

FIgURE 11: Effect of retorting temperature on total content of n-alkanes and n-alkenes.

the increase of the retorting temperature. But the increase number of $n$-alkanes was about half of the decrease number of $\mathrm{n}$-alkanes, indicating that the $\mathrm{n}$-alkanes may participate in the reaction of aromatization, dehydrogenation, fracture, and other reactions in the pyrolysis process.

\section{Conclusion}

In this study, the yield of pyrolysates and characteristics of shale oil and retorting gas were obviously affected by retorting temperature carried out in laboratory-scale fixed-bed reactor for Longkou oil shale. The main results were the following:

(1) As the retorting temperature increased from 430 to $520^{\circ} \mathrm{C}$, the yield of shale oil and retorting gas increased while that of shale char decreased significantly. And retorting temperature with $550^{\circ} \mathrm{C}$ was optimal at $15^{\circ} \mathrm{C} / \mathrm{min}$ heating rate, ensuring maximum value of shale oil yield, $17.46 \%$

(2) As the retorting temperature increases, there were increases in $\mathrm{CH}_{4}, \mathrm{H}_{2}$, and $\mathrm{CO}_{2}$ while a decline of the ratio of alkanes/alkenes $\left(\mathrm{C}_{1}-\mathrm{C}_{5}\right)$ because of the gas secondary cracking reaction. At higher temperatures, alkanes were prone to decomposition and dehydrogenation due to lower bond energy, leading to higher olefin and $\mathrm{H}_{2}$ content

(3) Increasing the retorting temperature from 400 to $550^{\circ} \mathrm{C}$ caused aromatic fractions to slightly increase because of the cracking of aliphatic compounds or Diels-Alder type reactions at higher temperature. In addition, the decrease of saturate fraction can be also explained by the cracking of aliphatic compounds. The increase of asphaltene fraction could be interpreted by the pyrolysis mechanism of bitumen as the intermediate product, in which the higher temperature, the more asphaltene produced. It was worth noting that the retorting temperature had little effect on the distillation range distribution of shale oil

(4) Increasing retorting temperature increased the carbon and nitrogen content, while decreased that of hydrogen and oxygen, and the atomic $\mathrm{H} / \mathrm{C}$ ratio in the derived shale oil. This decrease of the atomic $\mathrm{H} / \mathrm{C}$ ratio was caused by the aromatization, dehydrogenation, and coking reactions in the higher temperature. The decrease of oxygen was also reflected by the decomposition of the oxygen-containing functional groups. The increase of the nitrogen content was linked to the aromatization reaction, which was converted to form the polycyclic aromatic nitrogenous compounds in the high temperature. The sulfur content was not significantly affected by increasing retorting temperature due to its stability

(5) The concentration more than $20 \mathrm{mg} / \mathrm{g}_{\text {oil }}$ was $\mathrm{C}_{23}-\mathrm{C}_{30}$ in the range of $400-550^{\circ} \mathrm{C}$. The concentration of alkanes $\left(\mathrm{C}_{8}-\mathrm{C}_{15}\right)$ and alkenes $\left(\mathrm{C}_{8}-\mathrm{C}_{12}\right)$ increased, whereas the total content of n-alkanes $\left(\mathrm{C}_{8^{-}}{ }_{34}\right)$ decreased from $402.91 \mathrm{mg} / \mathrm{g}_{\text {oil }}$ to $369.25 \mathrm{mg} / \mathrm{g}_{\text {oil }}$ and that of n-alkene reached the maximum value at $550^{\circ} \mathrm{C}, 181.62 \mathrm{mg} / \mathrm{g}_{\text {oil }}$ with the rise of final retorting temperature, indicating that the $\mathrm{n}$-alkanes may participate in the reaction of aromatization, dehydrogenation, fraction, and other reactions in the pyrolysis process

\section{Data Availability}

The data used to support the findings of this study are available from the corresponding author (Pro. Jiancun Gao) upon request. 


\section{Conflicts of Interest}

The authors declare that they have no conflicts of interest.

\section{Authors' Contributions}

Wei Wang and Yue Ma contributed equally to this work.

\section{Acknowledgments}

The project was supported by the Natural Science Foundation of Beijing, China (General Program, No. 2214071). We are grateful to Pro. Q. Shi from China University of Petroleum-Beijing for GC-MS analysis support.

\section{References}

[1] Z. Chen, Y. Tian, D. Lai et al., "Oil shale pyrolysis in a moving bed with internals enhanced by rapid preheating in a heated drop tube," Energy Conversion and Management., vol. 224, p. 113358, 2020.

[2] H. Zhou, H. Li, R. Duan, and Q. Yang, "An integrated scheme of coal-assisted oil shale efficient pyrolysis and high-value conversion of pyrolysis oil," Energy, vol. 196, pp. 117106117106.15, 2020.

[3] B. Liu, A. Bechtel, R. F. Sachsenhofer, D. Gross, R. Gratzer, and $\mathrm{X}$. Chen, "Depositional environment of oil shale within the second member of Permian Lucaogou Formation in the Santanghu Basin, Northwest China," International Journal of Coal Geology., vol. 175, pp. 10-25, 2017.

[4] B. Liu, L. Bai, Y. Chi, R. Jia, X. Fu, and L. Yang, "Geochemical characterization and quantitative evaluation of shale oil reservoir by two-dimensional nuclear magnetic resonance and quantitative grain fluorescence on extract: a case study from the Qingshankou Formation in Southern Songliao Basin, northeast China," Marine and Petroleum Geology., vol. 109, pp. 561-573, 2019.

[5] W. Taciuk, "Does oil shale have a significant future?," Oil Shale., vol. 30, no. 1, pp. 1-5, 2013.

[6] J. G. Na, C. H. Im, S. H. Chung, and K. B. Lee, "Effect of oil shale retorting temperature on shale oil yield and properties," Fuel, vol. 95, pp. 131-135, 2012.

[7] S. Zhao, Y. Sun, X. Lü, and Q. Li, "Energy consumption and product release characteristics evaluation of oil shale nonisothermal pyrolysis based on TG-DSC," Journal of Petroleum Science and Engineering, vol. 187, p. 106812, 2020.

[8] S. Wang, J. X. Liu, X. M. Jiang, X. X. Han, and J. H. Tong, "Effect of heating rate on products yield and characteristics of non-condensable gases and shale oil obtained by retorting Dachengzi oil shale," Oil Shale, vol. 30, no. 1, pp. 27-47, 2013.

[9] S. Wang, X. Jiang, X. Han, and J. Tong, "Effect of retorting temperature on product yield and characteristics of noncondensable gases and shale oil obtained by retorting Huadian oil shales," Fuel Processing Technology., vol. 121, pp. 9-15, 2014.

[10] W. Wang, Y. Ma, S. Y. Li, C. Yue, J. Wu, and J. Teng, "Pyrolysis characteristics of Longkou oil shale under optimized condition," Journal of Thermal Analysis and Calorimetry., vol. 125, no. 2, pp. 983-990, 2016.
[11] P. Tiwari and M. Deo, "Compositional and kinetic analysis of oil shale pyrolysis using TGA-MS," Fuel, vol. 94, no. 1, pp. 333-341, 2012.

[12] N. V. Dung, "Factors affecting product yields and oil quality during retorting of Stuart oil shale with recycled shale: a screening study," Fuel, vol. 74, no. 4, pp. 623627, 1995.

[13] J. O. Jaber and S. D. Probert, "Non-isothermal thermogravimetry and decomposition kinetics of two Jordanian oil shales under different processing conditions," Fuel Processing Technology., vol. 63, no. 1, pp. 57-70, 2000.

[14] O. S. Al-Ayed, A. Al-Harahsheh, A. M. Khaleel, and M. Al-Harahsheh, "Oil shale pyrolysis in fixed-bed retort with different heating rates," Oil Shale, vol. 26, no. 2, pp. 139-147, 2009.

[15] A. M. Khalil, "Oil shale pyrolysis and effect of particle size on the composition of shale oil," Oil Shale, vol. 30, no. 2, pp. 136-146, 2013.

[16] S. Y. Li and C. T. Yue, "Study of pyrolysis kinetics of oil shale," Fuel, vol. 82, no. 3, pp. 337-342, 2003.

[17] M. Abu-Qudais, J. O. Jaber, and S. Sawalha, "Kinetics of pyrolysis of Attarat oil shale by thermogravimetry," Oil Shale., vol. 22, no. 1, pp. 51-63, 2006.

[18] Ö. M. Doğan and B. Z. Uysal, "Non-isothermal pyrolysis kinetics of three Turkish oil shales," Fuel, vol. 75, no. 12, pp. 1424-1428, 1996.

[19] M. C. Torrente and M. A. Galan, "Kinetics of the thermal decomposition of oil shale from Puertollano (Spain)," Fuel, vol. 80, no. 3, pp. 327-334, 2001.

[20] M. V. Mustafa Versan Kok and I. Senguler, "Geological and thermal characterization of Eskișehir region oil shales," Journal of Thermal Analysis and Calorimetry., vol. 116, no. 1, pp. 367-372, 2014.

[21] P. T. Williams and H. M. Chisti, "Reaction of nitrogen and sulphur compounds during catalytic hydrotreatment of shale oil," Fuel, vol. 80, no. 7, pp. 957-963, 2001.

[22] J. Zhang, Y. M. Ding, W. du, K. Lu, and L. Sun, "Study on pyrolysis kinetics and reaction mechanism of Beizao oil shale," Fuel, vol. 296, p. 120696, 2021, in press.

[23] X. X. Han, X. M. Jiang, and Z. G. Cui, "Studies of the effect of retorting factors on the yield of shale oil for a new comprehensive utilization technology of oil shale," Applied Energy., vol. 86, no. 11, pp. 2381-2385, 2009.

[24] V. N. Dung, "Yields and chemical characteristics of products from fluidized bed steam retorting of Condor and Stuart oil shales: effect of pyrolysis temperature," Fuel, vol. 69, no. 3, pp. 368-376, 1990.

[25] P. T. Williams and J. M. Nazzal, "Pyrolysis of oil shales: influence of particle grain size on polycyclic aromatic compounds in the derived shale oil," Journal of the Energy Institute., vol. 72, no. 491, pp. 48-55, 1999.

[26] A. K. Burnham and R. L. Ward, "A possible mechanism of alkene/alkane production in oil shale retorting," ACS Division of Fuel Chemistry., vol. 25, pp. 82-88, 1980.

[27] J. H. Raley, "Monitoring oil shale retorts by off-gas alkene/alkane ratios," Fuel, vol. 59, no. 6, pp. 419-424, 1980.

[28] P. T. Williams and J. M. Nazzal, "Polycyclic aromatic compounds in oils derived from the fluidised bed pyrolysis of oil shale," Journal of Analytical and Applied Pyrolysis., vol. 35, no. 2, pp. 181-197, 1995. 
[29] P. T. Williams and J. M. Nazzal, "Polycyclic aromatic compounds in shale oils: influence of process conditions," Environmental Technology., vol. 19, no. 8, pp. 775-787, 1998.

[30] L. S. Kuangzong and Z. Yajie, "Study of the kinetics of oil shale pyrolysis with bitumen as an intermediate product," Journal of Fuel Chemistry Technology., vol. 15, no. 2, pp. 118-123, 1987. 